\title{
High temporal frequency measurements of greenhouse gas emissions from soils
}

\author{
K. Savage ${ }^{1}$, R. Phillips ${ }^{2}$, and E. Davidson ${ }^{1}$ \\ ${ }^{1}$ The Woods Hole Research Center, 149 Woods Hole Rd, Falmouth, MA 02540, USA \\ ${ }^{2}$ Landcare Research, Riddett Road, Massey University, Palmerston North, 4472, New Zealand \\ Correspondence to: K. Savage (savage@whrc.org)
}

Received: 18 October 2013 - Published in Biogeosciences Discuss.: 25 November 2013

Revised: 14 March 2014 - Accepted: 27 March 2014 - Published: 21 May 2014

\begin{abstract}
Carbon dioxide $\left(\mathrm{CO}_{2}\right)$, methane $\left(\mathrm{CH}_{4}\right)$, and nitrous oxide $\left(\mathrm{N}_{2} \mathrm{O}\right)$ are the most important anthropogenic greenhouse gases (GHGs). Variation in soil moisture can be very dynamic, and it is one of the dominant factors controlling the net exchange of these three GHGs. Although technologies for high-frequency, precise measurements of $\mathrm{CO}_{2}$ have been available for years, methods for measuring soil fluxes of $\mathrm{CH}_{4}$ and $\mathrm{N}_{2} \mathrm{O}$ at high temporal frequency have been hampered by lack of appropriate technology for in situ real-time measurements. A previously developed automated chamber system for measuring $\mathrm{CO}_{2}$ flux from soils was configured to run in line with a new quantum cascade laser (QCLAS) instrument that measures $\mathrm{N}_{2} \mathrm{O}$ and $\mathrm{CH}_{4}$. Here we present data from a forested wetland in Maine and an agricultural field in North Dakota, which provided examples of both net uptake and production for $\mathrm{N}_{2} \mathrm{O}$ and $\mathrm{CH}_{4}$. The objective was to provide a range of conditions in which to run the new system and to compare results to a traditional manual static-chamber method.

The high-precision and more-than-10-times-lower minimum detectable flux of the QCLAS system, compared to the manual system, provided confidence in measurements of small $\mathrm{N}_{2} \mathrm{O}$ uptake in the forested wetland. At the agricultural field, the greatest difference between the automated and manual sampling systems came from the effect of the relatively infrequent manual sampling of the high spatial variation, or "hot spots", in GHG fluxes. Hot spots greatly influenced the seasonal estimates, particularly for $\mathrm{N}_{2} \mathrm{O}$, over one 74-day alfalfa crop cycle. The high temporal frequency of the automated system clearly characterized the transient response of all three GHGs to precipitation and demonstrated a clear diel pattern related to temperature for GHGs. A combination
\end{abstract}

of high-frequency automated and spatially distributed chambers would be ideal for characterizing hot spots and "hot moments" of GHG fluxes.

\section{Introduction}

The production and transport of $\mathrm{CO}_{2}, \mathrm{CH}_{4}$, and $\mathrm{N}_{2} \mathrm{O}$ in soils is strongly affected by changes in soil temperature and moisture through diel cycles, wet-up and dry-down events, management practices, seasonal patterns, and interannual variation in climate (Davidson and Schimel, 1995; Borken et al., 2006; Davidson et al., 2006). Microbial decomposition of soil organic matter and root respiration are the dominant sources of $\mathrm{CO}_{2}$ production. The microbial processes of nitrification and denitrification are the dominant sources of $\mathrm{N}_{2} \mathrm{O}$ (Firestone and Davidson, 1989), and these soil microbial processes are subject to rapid responses to wetting and thawing events (Davidson, 1992). There is growing evidence of an occasional net sink of $\mathrm{N}_{2} \mathrm{O}$ in soils (Chapuis-Lardy et al., 2007; Schlesinger, 2013), but elucidation of this process has been hampered, in part, by lack of sufficient sensitivity and frequency of $\mathrm{N}_{2} \mathrm{O}$ flux measurements. Methane is produced under anaerobic conditions by methanogenic bacteria and consumed under aerobic conditions by methanotrophic bacteria (Davidson and Schimel, 1995). Hence the balance between release and uptake of $\mathrm{CH}_{4}$ from soils is dependent largely on soil moisture status, which can change rapidly with precipitation events. Fluxes associated with precipitation events are difficult to study if humans must be present to make measurements immediately before, during, and after storms. 
Reliable and continuous automated systems are needed for measuring fluxes of $\mathrm{CH}_{4}$ and $\mathrm{N}_{2} \mathrm{O}$ to determine how short-term variation in moisture, temperature, and rhizosphere activity, as well as human management practices such as tillage and fertilization, influence production, consumption, and transport of these soil gases. The static-chamber technique involves manual collection of gas data over a time course $(<1 \mathrm{~h})$ using vials that are subsequently analyzed by gas chromatography (GC) in the laboratory (Verchot et al., 1999, 2000; Davidson et al., 2008; Phillips et al., 2009) and can be labor-intensive and time-consuming. Manual fluxes are typically measured once per day, week, or month and often only during daylight hours. While the manual chamber technique for greenhouse gas (GHG) flux measurement is widely accepted, the lack of diurnal data, particularly for $\mathrm{CH}_{4}$ and $\mathrm{N}_{2} \mathrm{O}$ fluxes, may compromise emission estimates. Estimates of annual fluxes from soils may also be subject to error if short-term responses to climatic variation and management interventions are inadequately sampled by infrequent manual measurements (Savage et al., 2008). Opportunities for mitigation efforts to reduce emissions of $\mathrm{CO}_{2}$, $\mathrm{CH}_{4}$ and $\mathrm{N}_{2} \mathrm{O}$ could be missed due to lack of understanding of transient spikes in emissions of these gases in response to rapidly changing environmental conditions.

With manual sampling using GC, it is usually necessary to leave a chamber over the soil for $20 \mathrm{~min}$ or more in order to detect a significant change in $\mathrm{CH}_{4}$ or $\mathrm{N}_{2} \mathrm{O}$ concentration in the chamber headspace. Leaving a chamber in place for this long can affect concentration gradients of these gases within the soil profile under the chamber, thus causing a bias in the estimated flux (Davidson et al., 2002). In the case of $\mathrm{CO}_{2}$, the availability of fast-response, portable infrared gas analyzers allows in situ methods for measuring soil $\mathrm{CO}_{2}$ flux, with the chamber over the soil for only $5 \mathrm{~min}$ or less (Davidson and Trumbore, 1995), thus minimizing the artifact of altering diffusion gradients. Current generation of newly available laser technology, which can measure $\mathrm{CH}_{4}$ and $\mathrm{N}_{2} \mathrm{O}$ at up to 10 $\mathrm{Hz}$, now provides an opportunity to make quicker measurements of these two important greenhouse gases at the surface of soils at high temporal frequencies.

We had previously developed an automated system for measuring soil respiration at high temporal frequency (every $30 \mathrm{~min}$ ) using an infrared gas analyzer (Savage and Davidson, 2003; Savage et al., 2008). These high-frequency measurements provided valuable insight into transient responses of soil respiration to precipitation events, which may be missed using a manual approach (Savage et al., 2009). Here we describe the technical details and methodologies to integrate an automated soil respiration system with a newly available quantum cascade laser (QCLAS), which measures $\mathrm{N}_{2} \mathrm{O}, \mathrm{CH}_{4}$ and $\mathrm{H}_{2} \mathrm{O}$ at $10 \mathrm{~Hz}$ (Aerodyne Research Inc., Billerica, MA). This automated method will enable continual, high-frequency, simultaneous measurements of the three most important greenhouse gases from soils. Since this system was previously tested for $\mathrm{CO}_{2}$ flux (Savage et al., 2008), this manuscript will focus primarily on the integration, and precision of the QCLAS to measure $\mathrm{N}_{2} \mathrm{O}$ and $\mathrm{CH}_{4}$ fluxes at the soil surface.

The system was deployed in early autumn at a forested wetland site in Howland (ME). The following spring, the system was moved to an alfalfa agricultural site near Mandan (ND). Our purpose is not to compare forested wetland versus agricultural sites per se, but rather to provide a range of conditions in which to run the automated QCLAS chamber system through sensitivity tests. We then compare fluxes using the automated QCLAS with fluxes using manual static chambers for a full alfalfa crop cycle at the ND agricultural site.

\section{Materials and methods}

\subsection{Study sites}

\subsubsection{Howland Forest wetland}

The Howland Forest research site is located about $56 \mathrm{~km}$ north of Bangor, Maine $\left(45.20407^{\circ} \mathrm{N}, 68.74020^{\circ} \mathrm{W}\right)$. The forest is owned by the Northeast Wilderness Trust, which has dedicated the site to conservation and scientific research. Stands in this forest consist primarily of red spruce (Picea rubens Sarg.) and eastern hemlock (Tsuga canadensis (L.) Carr.). This stand was selectively logged (not clear-cut) early in the 1900 s, but has been minimally disturbed since that time. Soils range from well drained to very poorly drained over relatively small areas (Levine et al., 1994). Physical and chemical data on the soil are provided by Fernandez et al., (1993). Mean annual temperature is $+5.5^{\circ} \mathrm{C}$, and mean annual precipitation is about $1000 \mathrm{~mm}$.

The sampling location was in a forested wetland approximately $80 \mathrm{~m}$ from a climate-controlled instrument hut where the equipment was housed. This system was deployed at this location from mid-September to early November 2011 and consisted of four automated soil gas flux sampling chambers, each measured hourly. Chambers were placed in a forested wetland dominated by Sphagnum and peat. Peat depths were approximately $1 \mathrm{~m}$ in the area these chambers were placed. The water table was a few centimeters below the Sphagnum surface over the course of this sample period. Soil temperature was measured at $10 \mathrm{~cm}$ depth (Type-T thermocouple). Soil moisture was measured using the Campbell Scientific CS616 water content reflectometer probes, placed at $10 \mathrm{~cm}$ depth. Soil temperature and moisture were measured hourly and data stored on a Campbell Scientific CR10X datalogger (Campbell Scientific, Logan UT). Precipitation data are from the Howland Forest Ameriflux eddy covariance tower (D. Hollinger, US Forest Service personal communication, 2013). 


\subsubsection{North Dakota alfalfa field}

The agricultural site is located near Mandan, ND, USA $\left(46^{\circ} 46^{\prime} \mathrm{N}, 100^{\circ} 55^{\prime} \mathrm{W}\right)$. Soils are classified as TemvikWilton silt loam (Fine-silty, mixed, superactive, frigid Typic and Pachic Haplustolls; Soil Survey Staff, 2008). Climate at the study site is semiarid with mean annual temperature of $10^{\circ} \mathrm{C}$ and mean annual precipitation of $412 \mathrm{~mm}$. The study site was managed for annual grain production for over 50 years and was seeded to alfalfa (Medicago sativa, L.) in 2009 using a no-till drill $\left(8 \mathrm{~kg} \mathrm{seed} \mathrm{ha}^{-1}\right)$. The alfalfa crop is harvested for silage approximately two times per year, and the time period from regrowth to harvest is considered one crop cycle. Management input is limited to $6.7 \mathrm{~kg} \mathrm{~N} \mathrm{ha}^{-1}$ and $33 \mathrm{~kg} \mathrm{Pha}^{-1}$ as granular monoammonium phosphate in midMarch each year. Soil properties measured in fall 2008 indicated $\mathrm{C}, \mathrm{N}$, and $\mathrm{pH}$ were $24.0,2.3$, and $5.7 \mathrm{~g} \mathrm{~kg}^{-1}$, respectively (Phillips et al., 2009).

The automated chamber system was installed at the ND site and measurements commenced on 19 March 2012, 10 days following soil thaw, and continued for one full alfalfa crop cycle $(74 \mathrm{~d})$. Five automated chambers were set up in a semicircle, approximately $3 \mathrm{~m}$ apart. The gas analyzing equipment (IRGA and QCLAS) was housed in a climatecontrolled building approximately $15 \mathrm{~m}$ from chambers. A static chamber of similar shape and volume $\left(\sim 400 \mathrm{~cm}^{3}\right)$ to the automated chamber was located within $1 \mathrm{~m}$ of each automated chamber in a similar configuration. The site was also instrumented with a rain gauge (TR-525), a soil temperature probe (T105) placed $2 \mathrm{~cm}$ below the soil surface, an air temperature probe (FW05) located at the soil surface, and three soil moisture probes (CS615) placed horizontally $4 \mathrm{~cm}$ below the surface (Campbell Scientific, Logan, UT).

\subsection{Automated sampling system}

A schematic diagram of the automated system is shown in Fig. 1, which is similar to a previously developed automated system for measuring soil respiration (Savage and Davidson, 2003). For simplicity, Fig. 1 shows only three chambers and is not to scale. The chamber design is based upon that of Tim Savas and Jim Tang (Ecosystem Center, Marine Biology Laboratory, Woods Hole, Ma.). Briefly, chamber tops are $30.5 \mathrm{~cm}$ diameter schedule- 80 PVC piping cut to $12.7 \mathrm{~cm}$ lengths. A $0.13 \mathrm{~cm}$ thick schedule- 80 PVC sheet is cut to 30.5 circular diameter and fixed using PVC cement to one side of the cut piping, creating the chamber top. Collars are also made of the same schedule- $80 \mathrm{PVC}$ pipe, cut to $5.1 \mathrm{~cm}$ lengths and beveled on one site at about $0.13 \mathrm{~cm}$ from the end. This end of the collar is inserted into the soil surface to $\approx 5 \mathrm{~cm}$ depth. T-slot aluminum bar (MSC Industrial Supply, Melville, NY) is used to make the chamber structures which support the chamber top while being lifted or lowered onto the collar. Stainless steel Swagelock connectors (Cambridge Valve and Fitting, Billerica, MA) were used for all connec- tions between the chamber tops and the analyzing equipment. Flow from each of the chambers is through $6.35 \mathrm{~mm}$ Synflex tubing (Goodrich Sales, Geneva Il.) and is controlled by two sets of manifold mounted solenoid valves (Minuteman Controls, Wakefield, MA). One set of solenoids controls the flow from the closed chamber to the analyzers and the other set controls the return flow from the analyzers to the closed chamber. An air compressor supplies the pressurized air to a set of slider valves (Minuteman Controls, Wakefield, MA), connected to chamber pistons that lift and lower the chamber top. The compressor is set to supply $40 \mathrm{psi}$ of pressure, such that when the chamber top is in the down position, there is downward pressure sealing the chamber top to the collar. The timing of each of the chambers and the lifting and lowering of the chamber tops is controlled by a relay driver (Campbell Scientific, Logan, UT), such that when one chamber is activated, the relay driver turns on the flow control solenoids and activates the piston control solenoids to lower the chamber top onto the collar. A CR1000 datalogger (Campbell Scientific, Logan, UT) is used to control the timing of the relay driver, sending it a signal to turn on or off a chamber at a particular interval over a $1 \mathrm{~h}$ period.

The chamber air flows from the closed chamber first to the Licor 6252 IRGA (Licor, Lincoln NE) for $\mathrm{CO}_{2}$ measurement and then to the QCLAS for measurement of $\mathrm{CH}_{4}$, $\mathrm{N}_{2} \mathrm{O}$ and $\mathrm{H}_{2} \mathrm{O}$. For a complete description of the QCLAS instrument; see Nelson et al. (2004). Briefly, the QCLAS is thermoelectrically cooled, uses a $76 \mathrm{~m}$ pathlength, $0.5 \mathrm{~L}$ volume, and multiple pass absorption cell for sampling. The laser frequency for the QCLAS is $1271 \mathrm{~cm}^{-1}$ for each of $\mathrm{CH}_{4}$ and $\mathrm{N}_{2} \mathrm{O}$. The laser is thermoelectrically cooled (Thermocube) to $32^{\circ} \mathrm{C}$. The QCLAS operates at below ambient pressure (40 Torr) and for this reason needs to be downstream of the IRGA, which operates at ambient pressure. A dual head diaphragm pump (KNF Neuberger, Trenton, NJ) maintains a steady flow rate of $0.8 \mathrm{~L} \mathrm{~min}^{-1}$ from chambers to the QCLAS. A datalogger (Campbell Scientific CR1000) records IRGA and QCLAS data at $1 \mathrm{~Hz}$. Analog output is sent from the IRGA to the logger and QCLAS data are sent to the logger through an RS232 cable. Calibration gases were automatically run through the IRGA and QCLAS using the QCLAS built-in solenoid valve system. Flow from a calibration gas is toggled on and allowed to flow for 2 min through the IRGA and the QCLAS, and outflow is vented to the atmosphere.

At both Howland Forest and North Dakota, each chamber was sampled once per hour. Each chamber was active for $10 \mathrm{~min}$ with $2 \mathrm{~min}$ to flush the tubing lines and $8 \mathrm{~min}$ when the chamber top was down over the collar. Gas concentrations were corrected for water vapor interference using the QCLAS $\mathrm{H}_{2} \mathrm{O}$ concentration data. Automated fluxes were calculated using measurements collected over a 4 min time period, beginning $60 \mathrm{~s}$ after the chamber top closed to $300 \mathrm{~s}$ into the run. Fluxes were calculated from a linear regression of change in headspace concentration over time and 


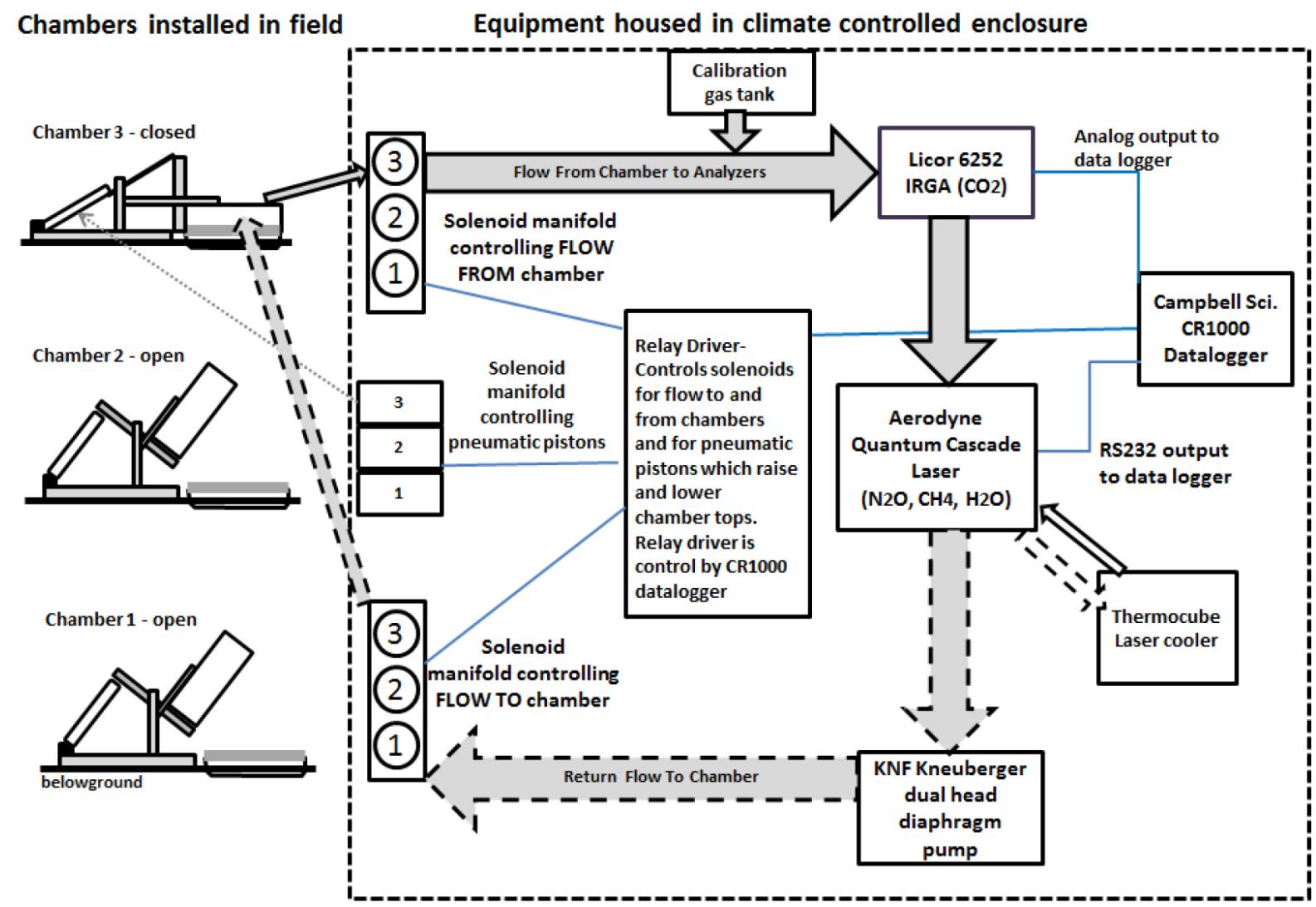

Figure 1. Schematic of 3 chambers and automated sampling system (diagram is not to scale). Solid grey arrows show air flow coming through tubing from closed chamber 3 to IRGA, then QCLAS. The dashed grey arrows are return flow via the diaphragm pump and back to closed chamber 3. Thermocube dashed lines indicate flow of $25 \%$ ethanol to cool the QCLAS and then return. Blue lines are wire connections between the instruments, datalogger and peripherals. An air compressor is used to supply the pressure for pneumatic pistons that raise and lower the chamber tops. The three chambers on the left show the chamber tops in the sampling position (chamber 3 ) and in the open nonsampling position (chambers 1,2). Only one chamber is in the closed position at any one time. All the equipment within the dashed square is housed in an environmentally protected, temperature-controlled enclosure.

were scaled to the collar area, corrected for atmospheric pressure and temperature.

\subsection{Manual sampling technique}

Manual chamber flux data were collected three times per week between 09:00 and 12:00 LT, from March through June 2012 , in conjunction with the automated chamber flux data. Collars were made of $25 \mathrm{~cm}$ diameter polyvinyl chloride (PVC) tubing cut to $25 \mathrm{~cm}$ lengths and inserted into the ground to a depth of $10 \mathrm{~cm}$. A vented PVC chamber top was fit securely over the collars to create a closed static chamber during sampling. Chamber height, including collar, was $20 \mathrm{~cm}$. Details of this measurement technique are described in detail by Phillips et al. (2009). Briefly, four headspace samples $(15 \mathrm{~mL}$ ) were sampled every $6 \mathrm{~min}$ (total time $18 \mathrm{~min}$ ), and were then immediately injected into evacuated, $12 \mathrm{~mL}$ exetainers (Labco Unlimited, Buckinghamshire, UK). Vials used for manual gas sample collection were com- pletely evacuated with a heavy-duty vacuum pump (Welch Model 1405, Skokie, IL) no more than $1 \mathrm{~h}$ prior to field sampling. A pressurized sample was injected into this fixed volume to avoid contamination during gas chromatography (Rochette and Eriksen-Hamel, 2008). Samples were not stored but instead analyzed immediately following field data collection. Quality of sample vial preparation, handling and analysis was checked using standards of known gas concentrations at each field sampling. These samples were analyzed for $\mathrm{CO}_{2}, \mathrm{~N}_{2} \mathrm{O}$ and $\mathrm{CH}_{4}$ with a Varian (Varian Inc., Walnut Creek, CA) Model 3800 Gas Chromatograph and Combi-PAL autosampler (Phillips et al., 2009). Manual fluxes were calculated using 4 measurements collected over an $18 \mathrm{~min}$ time period. Fluxes were calculated from the change in chamber headspace concentration over time in the same manner as those from the automated system. 


\subsection{Instrument accuracy and precision}

According to QCLAS factory specifications, the range for $\mathrm{N}_{2} \mathrm{O}$ measurements is 0.3 to $3000 \mathrm{ppb}$ at $10 \mathrm{~Hz}$, with a sensitivity of $0.3 \mathrm{ppb}$. The range for $\mathrm{CH}_{4}$ measurements is 0.5 to $5000 \mathrm{ppb}$ at $10 \mathrm{~Hz}$, with a sensitivity of $0.5 \mathrm{ppb}$. Specifically for our purposes of measuring GHG flux from soils, we configured the QCLAS to sample at a $1 \mathrm{~Hz}$ frequency. Two tanks of high-precision NOAA (National Oceanic and Atmospheric Administration) standards (NOAA/ESRL/GMD, Boulder, $\mathrm{CO}$ ) were used to determine QCLAS precision and accuracy for $\mathrm{N}_{2} \mathrm{O}$ and $\mathrm{CH}_{4}$ (Table 1). The absolute $\mathrm{N}_{2} \mathrm{O}$ concentrations measured at the QCLAS were within $1 \%$ of the NOAA standard for concentrations above and below ambient. The absolute $\mathrm{CH}_{4}$ concentrations measured at the QCLAS were $7 \%$ greater than the NOAA standard for concentrations above and below ambient. $\mathrm{CH}_{4}$ and $\mathrm{N}_{2} \mathrm{O}$ concentrations were corrected for this measurements difference post-data processing. The absolute concentration difference for $\mathrm{CH}_{4}$ standards may be indicative of peak interpretation within the QCLAS as the instrument is tuned specifically on interpreting the $\mathrm{N}_{2} \mathrm{O}$ gas peak. Precision (relative standard deviation) for $\mathrm{N}_{2} \mathrm{O}$ was $0.04 \mathrm{ppb}$ at both concentrations (Table 1). The precision for $\mathrm{CH}_{4}$ was $0.31 \mathrm{ppb}$ at $2116.27 \mathrm{ppb}$ and $0.26 \mathrm{ppb}$ at $1764.63 \mathrm{ppb}$ (Table 1). Levels of precision higher than factory specifications were likely achieved by the lower QCLAS sampling frequency $(1 \mathrm{~Hz})$.

The precision of GC analysis, expressed as a coefficient of variation for 10 replicate injections of a low concentration standard (2000 ppb for $\mathrm{CH}_{4}$ and $363.7 \mathrm{ppb} \mathrm{N}_{2} \mathrm{O}$ ) and a high concentration standard (10000 ppb for $\mathrm{CH}_{4}$ and 1682.1 ppb $\mathrm{N}_{2} \mathrm{O}$ ), was consistently $<2 \%$ for both gases.

\subsection{Diel trends in GHGs}

Diel trends in GHG fluxes were examined specifically in the ND data set as it comprised a full growing alfalfa crop cycle. Diel patterns of GHGs were modeled using a sine wave function (see Savage et al., 2013):

$$
R=\text { yo }+A \times \operatorname{sine}\left(\left(\frac{2 \times \pi \times \mathrm{TOD}}{2400}\right)+c\right),
$$

where yo represents the mean flux over the time period modeled, $A$ is diel amplitude, $c$ corresponds to the shift of minimum and maximum diel peaks (radians) and TOD is time of day in hundreds. Units for yo and $A$ are the same as the flux units for the GHG modeled. Bootstrapping 1000 model fits (R 2.7.1) was used to determine $95 \%$ confidence intervals around model parameters.

\section{Results and discussion}

The high temporal frequency automated measurements of GHGs from a forested wetland in Howland, ME, and an agricultural site in Mandan, ND, provided a range of conditions in which to run the automated QCLAS chamber system through sensitivity tests and compare these with fluxes measured using the manual static-chamber GC technique.

\subsection{Minimum detectable fluxes of $\mathrm{N}_{2} \mathrm{O}$ and $\mathrm{CH}_{4}$}

Calculations of minimum detectable fluxes (MDFs) of $\mathrm{N}_{2} \mathrm{O}$ and $\mathrm{CH}_{4}$ for manual chamber-based measurements from North Dakota were made following the methodologies developed by Parkin et al. (2012) as this methodology fit with the manual sampling technique (Sect. 2.3). Minimum detectable fluxes for the automated chamber system at both Howland Forest and at ND were determined by both the Parkin et al. (2012) method and by the Verchot et al. (1999) method.

The Parkin method was used to calculate the MDF for the manual static chambers from the ND site, which used a GC to analyze GHG concentrations. Ten ambient air samples were taken in the same method as manually collected gas flux samples, and these data were used to define the coefficient of variation $(\mathrm{CV})$ for $\mathrm{N}_{2} \mathrm{O}$ and $\mathrm{CH}_{4}$. We used the four-point linear regression sampling coefficients provided in their methodologies to determine the MDF for each gas. Minimum detectable fluxes were $\pm 0.70 \mu \mathrm{g} \mathrm{N}_{2} \mathrm{O}-\mathrm{N} \mathrm{m}^{-2} \mathrm{~h}^{-1}$ for $\mathrm{N}_{2} \mathrm{O}$ and $\pm 3.32 \mu \mathrm{g} \mathrm{CH} \mathrm{CH}_{4}-\mathrm{C} \mathrm{m}^{-2} \mathrm{~h}^{-1}$ for $\mathrm{CH}_{4}$.

For comparison of MDF between the automated and manual system we used the Parkin et al. (2012) method for the automated systems at Howland Forest and at ND. Automated chambers at Howland Forest and at ND collected ambient air for $3 \mathrm{~min}(n=180)$, and these data were used to determine the mean and coefficient of variation (CV) for $\mathrm{N}_{2} \mathrm{O}$ and $\mathrm{CH}_{4}$. The MDFs for the automated system at Howland Forest were $\pm 0.01 \mu \mathrm{g} \mathrm{N}_{2} \mathrm{O}-\mathrm{N} \mathrm{m}^{-2} \mathrm{~h}^{-1}$ and $\pm 0.03 \mu \mathrm{g} \mathrm{CH} \mathrm{CH}_{4}-\mathrm{Cm}^{-2} \mathrm{~h}^{-1}$. The MDFs using the automated system in ND were $\pm 0.05 \mu \mathrm{g} \mathrm{N} \mathrm{N}_{2} \mathrm{O}-\mathrm{N} \mathrm{m}^{-2} \mathrm{~h}^{-1}$ and $\pm 0.18 \mu \mathrm{g} \mathrm{CH} \mathrm{CH}_{4}-\mathrm{C} \mathrm{m}^{-2} \mathrm{~h}^{-1}$.

Since the Parkin method was not developed for automated systems with greater than four sample points per chamber flux measurement, we further calculated MDF using the method presented in Verchot et al., (1999). This method calculates the $95 \%$ confidence intervals around the slope of the change in headspace gas concentration over time and then bins fluxes and defines the MDF as the flux bin interval at which $>67 \%$ of the calculated fluxes have confidence intervals that do not include zero. We binned our fluxes at $0.05 \mu \mathrm{g} \mathrm{m}^{-2} \mathrm{~h}^{-1}$ (for $\mathrm{N}_{2} \mathrm{O}-\mathrm{N}$ or $\mathrm{CH}_{4}-\mathrm{C}$ ) intervals and calculated the percentage of confidence intervals within each bin that include zero. Similar to Verchot, we used $67 \%$ as the cutoff for determining MDF. Using this method, the MDFs for the automated system at Howland Forest were $\pm 0.05 \mu \mathrm{g} \mathrm{N}_{2} \mathrm{O}-\mathrm{N} \mathrm{m}^{-2} \mathrm{~h}^{-1}$ and $\pm 0.12 \mu \mathrm{g} \mathrm{CH}_{4}$ $\mathrm{C} \mathrm{m}^{-2} \mathrm{~h}^{-1}$, and for ND were $\pm 0.07 \mu \mathrm{g} \mathrm{N} \mathrm{N}_{2} \mathrm{O}-\mathrm{N} \mathrm{m}^{-2} \mathrm{~h}^{-1}$ and $\pm 0.32 \mu \mathrm{g} \mathrm{CH} \mathrm{CH}_{4}-\mathrm{C} \mathrm{m}^{-2} \mathrm{~h}^{-1}$. It is likely that the higher MDFs calculated from ambient air samples at the ND site compared to the Howland Forest site may be indicative of the air 
Table 1. Comparison of QCLAS gas concentrations with NOAA high-precision calibration standards.

\begin{tabular}{llll}
\hline & $\begin{array}{l}\text { QCLAS } \\
(\mathrm{ppb})\end{array}$ & $\begin{array}{l}\text { NOAA calibration } \\
\text { standards }(\mathrm{ppb})\end{array}$ & $\begin{array}{l}\% \\
\text { difference }\end{array}$ \\
\hline $\mathrm{N}_{2} \mathrm{O}$-calibration gas & $353.24(0.04)$ & $353.63(0.15)$ & $-0.11 \%$ \\
$\mathrm{~N}_{2} \mathrm{O}$-calibration gas & $305.41(0.04)$ & $307.29(0.11)$ & $-0.61 \%$ \\
$\mathrm{CH}_{4}$-calibration gas & $2116.27(0.31)$ & $1975.02(0.30)$ & $7.1 \%$ \\
$\mathrm{CH}_{4}$-calibration gas & $1764.63(0.26)$ & $1644.15(0.30)$ & $7.3 \%$ \\
\hline
\end{tabular}

QCLAS data mean (standard deviation, SD) $(n=60)$.

Calibration gas are high-precision calibration gas standards. Values represent the average

measurement and (SD) represents the repeatability of a single calibration.

quality, where the location in ND is industrial/agricultural, whereas in Howland, Maine, the surrounding area is primarily forest.

The MDFs for the automated system determined using the Verchot method are higher than those determined by the Parkin method; however these MDFs are still low. The high precision of the QCLAS instrument gives greater confidence in the measurement of very low fluxes of both $\mathrm{N}_{2} \mathrm{O}$ and $\mathrm{CH}_{4}$ compared to the manual method.

\subsection{Frequency distribution of $\mathrm{N}_{2} \mathrm{O}$ and $\mathrm{CH}_{4}$ fluxes}

The purpose of using an automated sampling system is the ability to measure fluxes at high temporal frequencies without supervision. The drawback to this is determining if the automated system is functioning correctly unsupervised; e.g., are the chambers closing properly over the collar? Our previous extensive measurements of $\mathrm{CO}_{2}$ flux from soils (Savage et al., 2008) gives us confidence that there is a strong $\mathrm{CO}_{2}$ flux, characterized by a linear increase in $\Delta\left[\mathrm{CO}_{2}\right]$ in the chamber headspace. In contrast, $\mathrm{N}_{2} \mathrm{O}$ and $\mathrm{CH}_{4}$ fluxes are often small positive or negative values that are difficult to distinguish from a zero flux. The $R^{2}$ value of the linearly increasing $\Delta\left[\mathrm{CO}_{2}\right]$ was used as an indicator that the system was functioning correctly. When the $\Delta\left[\mathrm{CO}_{2}\right] R^{2}$ value was $\geq 0.90$, we have confidence that the system was operating correctly, and hence we also have confidence in the fluxes of $\mathrm{N}_{2} \mathrm{O}$ and $\mathrm{CH}_{4}$ measured concurrent to $\mathrm{CO}_{2}$. We assigned an $R^{2}$ of $<0.90$ for $\Delta\left[\mathrm{CO}_{2}\right]$ as an indication that there may have been an issue with the chamber closing and sealing correctly or another unknown problem, and we use this indicator of unreliable $\mathrm{CO}_{2}$ flux measurement to identify which $\mathrm{N}_{2} \mathrm{O}$ and $\mathrm{CH}_{4}$ concurrently measured fluxes were also unreliable.

The frequency distribution of $\mathrm{N}_{2} \mathrm{O}$ and $\mathrm{CH}_{4}$ fluxes at the Howland Forest wetland site and the North Dakota agricultural site (Fig. 2) are plotted separately for those fluxes that met the $R^{2} \geq 0.90$ criteria and those that did not meet those criteria $\left(R^{2}<0.90\right)$ for $\Delta\left[\mathrm{CO}_{2}\right] . \mathrm{N}_{2} \mathrm{O}$ and $\mathrm{CH}_{4}$ flux measurements that fell into the $\Delta\left[\mathrm{CO}_{2}\right] R^{2}<0.90$ category were normally distributed near zero, which would be expected for random error due to improper closing of the chamber. For this small percentage of fluxes that did not meet the
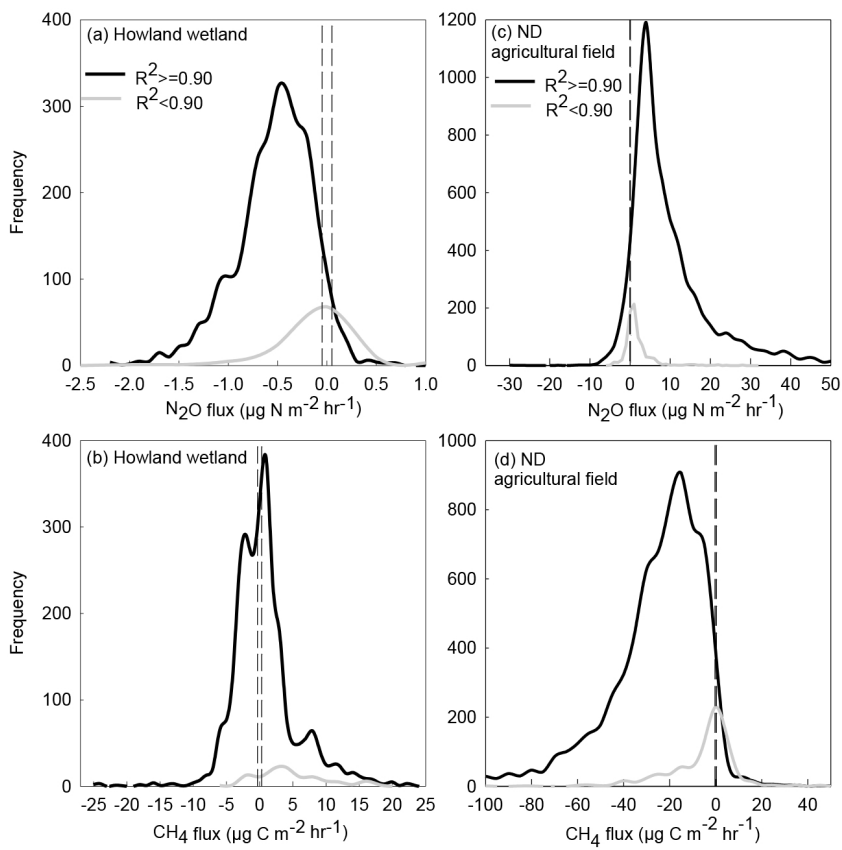

Figure 2. Frequency distribution of automated $\mathrm{N}_{2} \mathrm{O}$ and $\mathrm{CH}_{4}$ fluxes for Howland wetland and North Dakota agricultural field, stratified by criteria of whether simultaneous $\mathrm{CO}_{2}$ flux measurements were of high quality. When the $R^{2}$ values of the linear regression of the simultaneous $\mathrm{CO}_{2}$ flux measurements were $<0.90$, then it is assumed that the chambers did not function properly and that measurements of all three gas fluxes were unreliable. When the $R^{2}$ values of the linear regression of the simultaneous $\mathrm{CO}_{2}$ flux measurements were $>0.90$, it is assumed that the $\mathrm{N}_{2} \mathrm{O}$ and $\mathrm{CH}_{4}$ flux measurements are also reliable, including those that are below the detection limit (i.e., not significantly different from a flux of zero). Dashed lines indicate minimum detectable flux range calculated by the Verchot method (Sect. 3.1) for each gas. A total of $\approx 7400$ fluxes for each GHG were measured in North Dakota and $\approx 3000$ fluxes for each GHG in Howland Forest.

$\Delta\left[\mathrm{CO}_{2}\right] R^{2} \geq 0.90$ criteria, we considered all three GHG measurements suspect and did not use them in subsequent analysis.

At the Howland Forest wetland, for $96 \%$ of fluxes measured, we have confidence that the system was working 
correctly based on the $\Delta\left[\mathrm{CO}_{2}\right] R^{2} \geq 0.90$. Of that $96 \%$, $<4 \%$ of those fluxes fell below the MDF (using the Verchot method estimate of MDF; see Sect. 3.1) for either $\mathrm{N}_{2} \mathrm{O}$ or $\mathrm{CH}_{4}$ fluxes (Fig 2). In ND, $90 \%$ of fluxes measured met the $\Delta\left[\mathrm{CO}_{2}\right] R^{2} \geq 0.90$ criteria for confidence. Of those $90 \%$, $<2.5 \%$ fell below the MDF for either $\mathrm{N}_{2} \mathrm{O}$ or $\mathrm{CH}_{4}$ (Fig. 2). The $\mathrm{N}_{2} \mathrm{O}$ and $\mathrm{CH}_{4}$ measurements at each site that met the concurrent $\Delta\left[\mathrm{CO}_{2}\right] R^{2} \geq 0.90$ criterion but were below the minimum detectable $\mathrm{N}_{2} \mathrm{O}$ or $\mathrm{CH}_{4}$ flux were considered reliable $\mathrm{N}_{2} \mathrm{O}$ and $\mathrm{CH}_{4}$ flux measurements that were not statistically significantly different from zero. We did not change the values to zero, so as to avoid introducing bias in the population distribution of measurements, but we consider them equivalent to zero net flux. The populations of $\mathrm{N}_{2} \mathrm{O}$ and $\mathrm{CH}_{4}$ fluxes that met our reliability criterion were not normally distributed.

Since the manual measurements require supervision, it was assumed that the manual chamber was always properly sealed during each measurement; therefore no minimum linear criteria for $\Delta\left[\mathrm{CO}_{2}\right]$ were used as an indicator for proper chamber sealing as was used for the automated system flux data. For the manual measurements at the ND site, of the 190 samples measured over the 74-day period, $5 \%$ of $\mathrm{N}_{2} \mathrm{O}$ and $1 \%$ of $\mathrm{CH}_{4}$ fluxes were below the minimum detectable flux (see Sect. 3.1). All manually measured fluxes were used for subsequent analysis at their measured values, similarly to the automated fluxes.

\subsection{Forested wetland in Howland Forest}

High-precision measurements of the QCLAS system enabled the quantification of very small and sporadic production of $\mathrm{N}_{2} \mathrm{O}$ from these soils; however the consumption of $\mathrm{N}_{2} \mathrm{O}$ dominated the soil atmosphere exchange in the wetland at Howland Forest (Fig. 3a). Since the MDF for $\mathrm{N}_{2} \mathrm{O}$ was $\pm 0.05 \mu \mathrm{g} \mathrm{N} \mathrm{N}_{2} \mathrm{O}-\mathrm{N} \mathrm{m}^{-2} \mathrm{~h}^{-1}$, this provides confidence that the small $\mathrm{N}_{2} \mathrm{O}$ uptake (primarily in the -0.5 to $-1.5 \mu \mathrm{g} \mathrm{N} \mathrm{N}_{2} \mathrm{O}$ $\mathrm{N} \mathrm{m}^{-2} \mathrm{~h}^{-1}$ range) is a real phenomenon and not random variation within the detection limit of the system. These soils are nitrogen-limited (Fernandez et al., 1993); hence low $\mathrm{N}_{2} \mathrm{O}$ fluxes were expected. Consumption of $\mathrm{N}_{2} \mathrm{O}$ by soils has previously been observed (Chapuis-Lardy et al., 2007), but is often either doubted as not significantly different from zero or ignored. However, recent studies addressing this issue have found $\mathrm{N}_{2} \mathrm{O}$ consumption related to soil moisture and thick soil organic layers (Fraiser et al., 2010; Ullah and Moore, 2011; Schlesinger, 2013). The wetland site has both a thick organic layer and wet conditions. However, it should be cautioned that this was a short-term study conducted at the end of the snow-free season and we do not yet know if net consumption of $\mathrm{N}_{2} \mathrm{O}$ within these types of soils occurs during other seasons.

Methane varied between small production and consumption in the wetland (Fig. 3b). $\mathrm{CH}_{4}$ fluxes were higher after precipitation events in the wetland, and, for chambers that

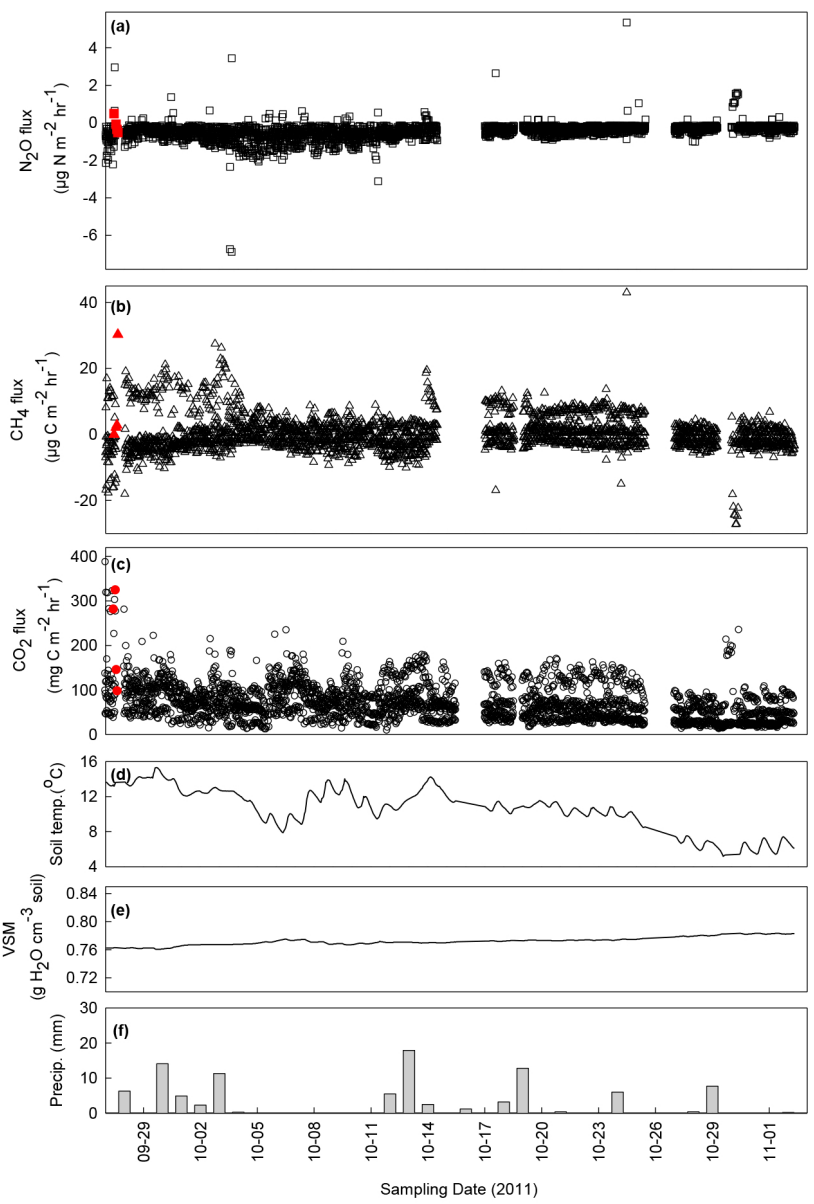

Figure 3. Howland Forest wetland data: (a) $\mathrm{N}_{2} \mathrm{O}$ flux, (b) $\mathrm{CH}_{4}$ flux, (c) $\mathrm{CO}_{2}$ flux, (d) soil temperature at $10 \mathrm{~cm}$ depth, (d) $\mathrm{VSM}=$ volumetric soil moisture at $10 \mathrm{~cm}$, (e) daily precipitation. Open black symbols are automated fluxes (five chambers); solid red symbols are manual fluxes (four chambers).

were consuming $\mathrm{CH}_{4}$, fluxes approached zero after rainfall, indicating that the balance between production and consumption was shifting. This small, transient shift in the balance between production and consumption in soils may be missed under less frequent sampling strategies.

Small episodic responses to precipitation events were evident among all three gases, with $\mathrm{N}_{2} \mathrm{O}, \mathrm{CH}_{4}$ and $\mathrm{CO}_{2}$ fluxes increasing, but no clear trend was evident from this short time period late in the snow-free season. Volumetric soil moisture in the wetland site varied little (Fig. 3) over the sampling period as the water table was near the surface; hence neither large nor small precipitation events influenced moisture greatly. In early September of 2011, one set of manual samples $(n=6)$ was taken from chambers located with $1 \mathrm{~m}$ of the automated chambers. The range of GHG fluxes calculated from these measurements agreed well with fluxes measured by the automated system on that sampling date (Fig. 3a, b and $\mathrm{c}$ red triangles). The automated fluxes of all three trace 
gases are in agreement with those measured in a deciduous forest in eastern Canada for a similar time period to this study (Ullah and Moore, 2011).

\subsection{Agricultural field in North Dakota}

Unlike the forested wetland site, the alfalfa field was consistently a source of $\mathrm{N}_{2} \mathrm{O}$ (Fig. 4a). Peaks in $\mathrm{N}_{2} \mathrm{O}$ emissions followed precipitation events most notably in late spring (Fig. 4a). Highest $\mathrm{N}_{2} \mathrm{O}$ flux values were measured near the end of April and in May, when microbial activity was likely stimulated by optimum soil temperature and moisture (Phillips et al., 2009). A few larger pulses were observed with the manual system, originating from two specific chambers, but were not present at the same time period for the automated chambers. The coefficient of variation $(\% \mathrm{CV})$ among the chambers sampled can be used as an indicator of spatial variability. The manual system had greater mean spatial variation in $\mathrm{N}_{2} \mathrm{O}$ flux among chambers (mean $=26 \mu \mathrm{g} \mathrm{m}^{-2} \mathrm{~h}^{-1}, \mathrm{CV}=90 \%$ ) compared to measurements from the automated chambers sampled concurrently with the manual chambers (mean $=9 \mu \mathrm{g} \mathrm{N} \mathrm{m}^{-2} \mathrm{~h}^{-1}$, $\mathrm{CV}=60 \%$ ). Much of the high spatial variation in $\mathrm{N}_{2} \mathrm{O}$ flux among the manual chambers came from a few chambers in April (Fig. 4a). These chambers may have captured what has been termed a "hot spot"; localized high microbial activity within the soil structure.

Methane fluxes had no clear regular temporal variation over the growing season. The manual method showed much greater variability of $\mathrm{CH}_{4}$ fluxes (Fig. $4 \mathrm{~b}$ ), with both consumption and some episodic net emissions of $\mathrm{CH}_{4}$, whereas the automated system showed consistent soil $\mathrm{CH}_{4}$ uptake. Mean spatial variation among the chambers sampled manually was greater (mean $=-36 \mu \mathrm{g} \mathrm{C} \mathrm{m}^{-2} \mathrm{~h}^{-1}, \mathrm{CV}=115 \%$ ) compared to the concurrent automated chamber measurements (mean $=-23 \mu \mathrm{g} \mathrm{m}^{-2} \mathrm{~h}^{-1}, \mathrm{CV}=57 \%$ ). However, it should be noted that the high spatial variation for the manually measured $\mathrm{CH}_{4}$ fluxes was evident throughout the growing season (Fig. 4b) as opposed to being attributed to specific dates as was seen for $\mathrm{N}_{2} \mathrm{O}$ fluxes. Episodic emissions of $\mathrm{CH}_{4}$ were not restricted to the same chambers.

Flux of $\mathrm{CO}_{2}$ showed the greatest agreement between methods, with the manual technique showing lower variation compared to the automated system (Fig. 4c). This may be a signal-to-noise phenomenon, whereby there is better agreement between methods when the fluxes are consistently above detection limits for $\mathrm{CO}_{2}$ and less often so for $\mathrm{N}_{2} \mathrm{O}$ and $\mathrm{CH}_{4}$. Spatial variation of $\mathrm{CO}_{2}$ fluxes observed among chambers was slightly lower (mean $=92 \mathrm{mg} \mathrm{C} \mathrm{m}^{-2} \mathrm{~h}^{-1}$, $\mathrm{CV}=30 \%$ ) for manually sampled compared to automated (mean $=104 \mathrm{mg} \mathrm{C} \mathrm{m}^{-2} \mathrm{~h}^{-1}, \mathrm{CV}=39 \%$ ). As has been previously observed (Savage et al., 2009), patterns of $\mathrm{CO}_{2}$ flux followed soil temperature trends and rapid transient pulses of $\mathrm{CO}_{2}$ were observed following precipitation events.
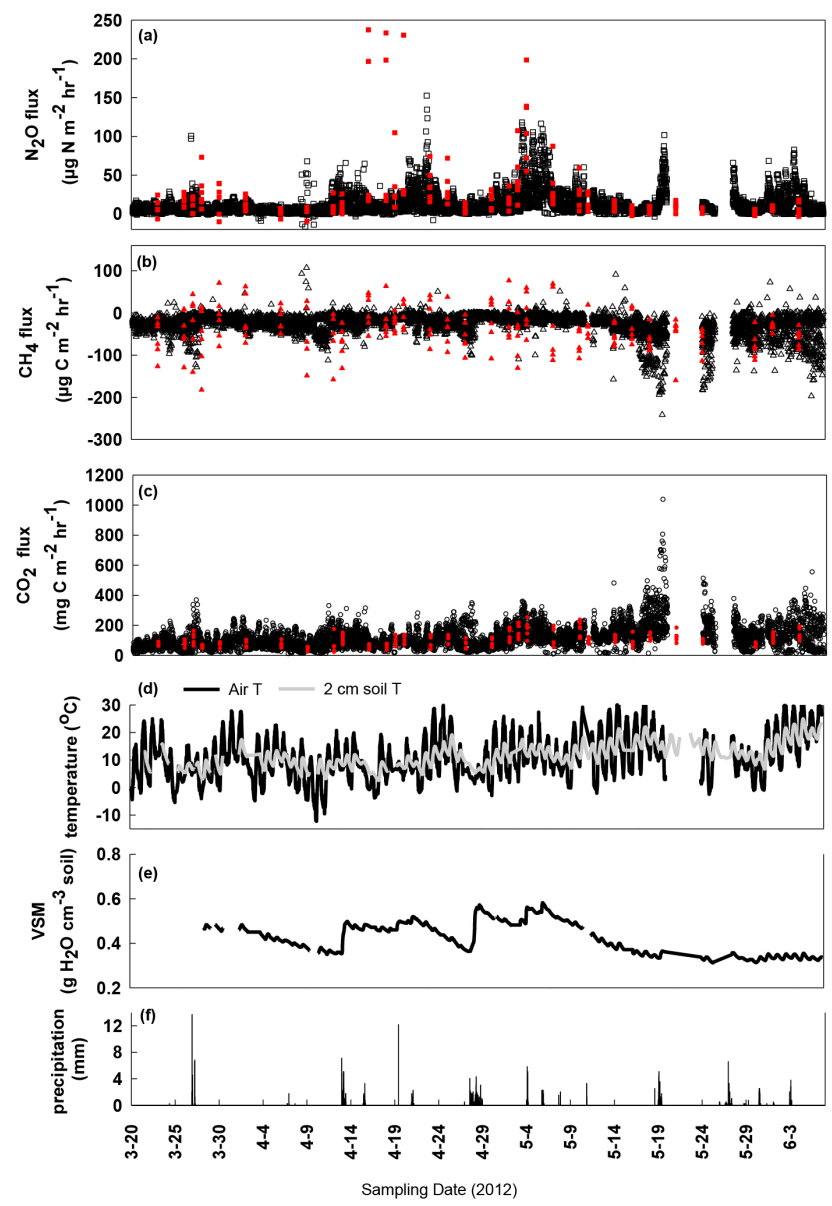

Figure 4. North Dakota alfalfa field: (a) $\mathrm{N}_{2} \mathrm{O}$ flux, (b) $\mathrm{CH}_{4}$ flux, (c) $\mathrm{CO}_{2}$ flux, (d) temperature, (e) VSM = volumetric soil moisture, (f) precipitation. Open black symbols are automated fluxes (five chambers); solid red symbols are manual fluxes (six chambers).

\subsection{Capturing transient responses to changes in soil moisture in North Dakota}

Automated and manual measurements of GHGs showed rapid, transient responses to precipitation events (Fig. 5). Increases in $\mathrm{N}_{2} \mathrm{O}$ and $\mathrm{CO}_{2}$ fluxes followed precipitation, with the greatest responses during the mid-growing season. Transient pulse responses of $\mathrm{N}_{2} \mathrm{O}$ and $\mathrm{CO}_{2}$ decreased over time from precipitation and subsequently as soil moisture decreased (Fig. 5a and c). The manually sampled chambers showed a greater initial response to precipitation, but as soils dried out there was good agreement across the sampling season between automated and manual measurements. Similarly, Smith and Dobbie (2001) found that temporal patterns observed using an intensive manual sampling strategy were similar across the season to an automated sampling system in two agricultural fields in Scotland.

Methane was generally consumed at this site; however during precipitation events $\mathrm{CH}_{4}$ fluxes approached zero 

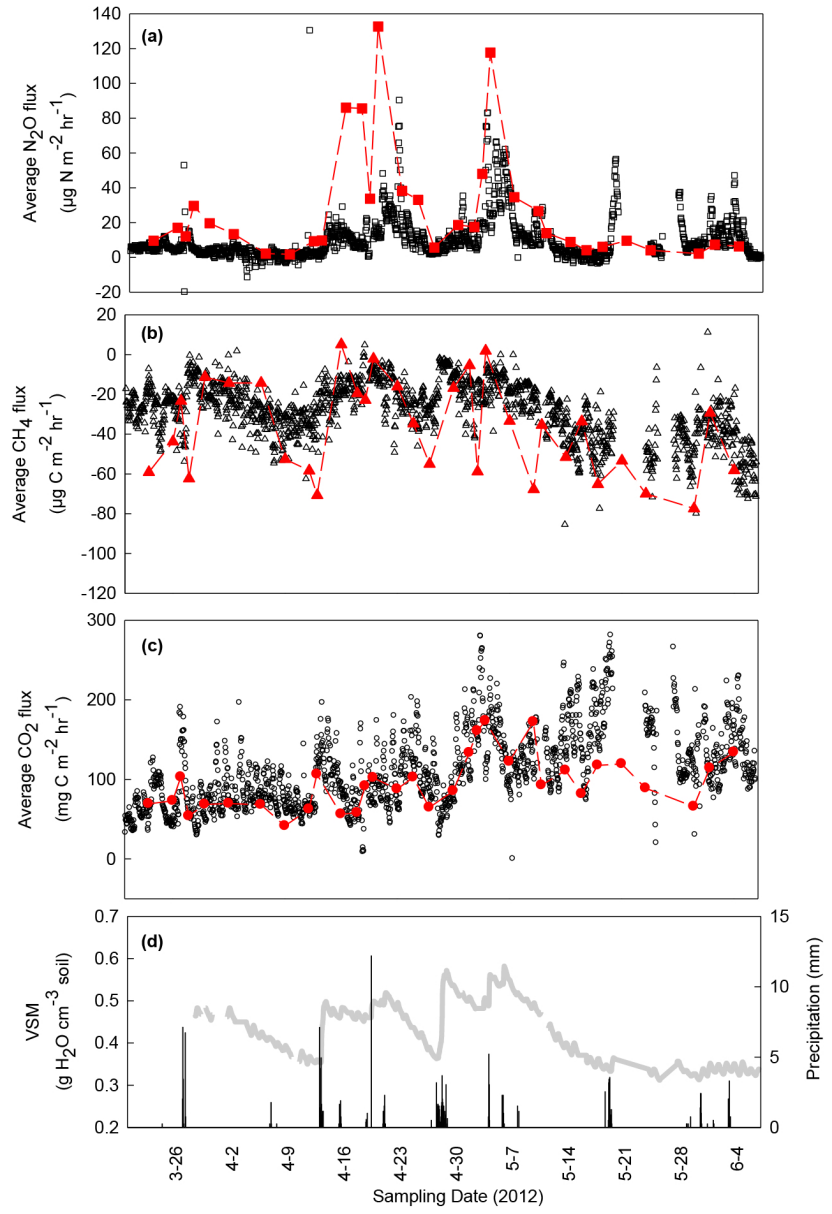

Figure 5. North Dakota hourly averaged fluxes for automated (black symbols, $n=5$ per hour) and manual (red symbols, $n=6$ per hour) measurements. (a) $\mathrm{N}_{2} \mathrm{O}$, (b) $\mathrm{CH}_{4}$, (c) $\mathrm{CO}_{2}$ flux. (d) Solid grey line is volumetric soil moisture and bars are hourly precipitation. Dotted lines connect the manual chamber flux measurement symbols in order to illustrate how interpolation between measurement dates affects the ND seasonal sum estimate (see text).

(Fig. 5), and as soils dried out greater rates of consumption were observed, particularly those measured from the manual chambers.

Carbon dioxide flux increase in response to precipitation is a result of increased microbial decomposition and is generally a function of the length of the antecedent dry period as well as the magnitude and duration of precipitation (Borken et al., 2006; Savage et al., 2009). This response was similarly characterized by both the manual sampling and automated systems.

The high temporal frequency of automated flux measurements of each GHG clearly defines the rise and decay characteristics of GHG response to precipitation wet-up and drydown of soils. The manual sampling strategy of three times per week at this ND site was also able to capture many of the transient GHG responses to precipitation events, although if a less frequent manual sampling strategy were adopted $(<3$ times per week) many of these responses may be missed.

\subsection{Manual and automated flux comparison}

Automated and manual measurements were conducted concurrently in ND between 23 March and 4 June 2012 (74 days). Manual and automated measurements taken at similar sample times $(n=136$; only data for which there were both automated and manual measurements available were used) and all the automated measurements $(n \approx 7400)$ for the crop cycle season are plotted in Fig. 6a, b and c. The range of variation in measured $\mathrm{N}_{2} \mathrm{O}$ and $\mathrm{CH}_{4}$ flux across the entire crop cycle season is much greater for the manual measurements compared to the concurrent automated measurements. However, the range of variation is similar between the manual fluxes and the entire season of automated measurement. It may be that, by random chance, the placement of some of the manual chambers captured hot spots missed by the placement of the automated chambers. However the highfrequency sampling of the automated system also captured a few "hot moments" missed by the less frequent manual sampling strategy (Fig. 5).

Seasonal crop cycle fluxes (over a 74-day measurement period) were determined for $\mathrm{CO}_{2}, \mathrm{CH}_{4}$ and $\mathrm{N}_{2} \mathrm{O}$ for each automated and manual chamber. Manual and concurrent automated fluxes were multiplied by 24 to obtain a daily flux, while all automated hourly fluxes were summed over the entire 74-day sampling period. Missing data were linearly interpolated between sample points for both manual and automated fluxes. A crop cycle sum was determined for each manual $(n=6)$ and each automated chamber $(n=5)$ and plotted in Fig. 6d, e and f. Up-scaling of the manual measurements to seasonal estimates lead to a greater range of seasonal crop estimates compared to the automated data. When calculating the manual seasonal estimates, fluxes were linearly interpolated between sample points. Because each manual chamber measurement affected the interpolated estimate for a 2-3-day period when calculating seasonal sums (see dotted lines in Fig. 5), the seasonal estimates from the manual method were clearly more strongly affected by the few hot spots and hot moments among manually sampled chambers. Although the range of variation in measured fluxes using the automated and manual system was similar across the entire season, any individual hot-spot and hot-moment flux had less influence on the overall seasonal estimate in the automated measurement data set because it was used to represent only one hour of emissions. Considerable differences in up-scaled estimates of $\mathrm{N}_{2} \mathrm{O}$ fluxes derived primarily from high spatial variation in $\mathrm{N}_{2} \mathrm{O}$ flux have also been observed in an agricultural field in Scotland (Smith and Dobbie, 2001). Smith and Dobbie (2001) and Parkin et al. (2008) found that up-scaled estimates of $\mathrm{N}_{2} \mathrm{O}$ flux from intensive manual sampling strategies (3-7 d intervals) were similar to those estimated from automated high temporal frequency chamber systems. These 

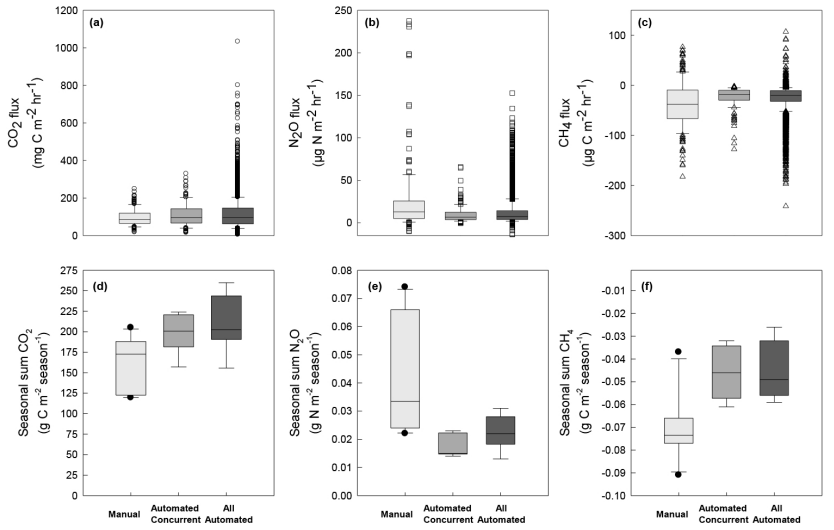

Figure 6. Box plots of individual fluxes measured in ND using the manual and automated methods. Data show manual samples (light grey), automated measurements concurrent to manual samples (dark grey) and all automated data (black). (a) $\mathrm{CO}_{2}$ flux, (b) $\mathrm{N}_{2} \mathrm{O}$ flux and (c) $\mathrm{CH}_{4}$ flux; $n=136$ for manual and concurrent automated fluxes and $n \approx 7400$ for all automated fluxes. Seasonal crop cycle sum (74 days) of (d) $\mathrm{CO}_{2}$, (e) $\mathrm{N}_{2} \mathrm{O}$ and (f) $\mathrm{CH}_{4}$. Manual and concurrent sums are interpolated and summed over the 74 days for each chamber, and all automated seasonal estimates are summed at an hourly timescale for the 74-day period for each chamber. The means and variance for seasonal sum estimates are based on $n=6$ manual chambers and $n=5$ automated chambers.

comparisons lend confidence to up-scaled estimates of $\mathrm{N}_{2} \mathrm{O}$ fluxes from intensive manual sampling strategies.

Comparison of manual and automated measurements indicates that there is considerable heterogeneity in GHG fluxes both spatially (hot spots) and temporally (hot moments). Ideally, a measurement system would include a few automated chambers with high temporal resolution of measurements and many more, less frequently sampled manual chambers to assess spatial variation.

\subsection{Diel trends in GHG fluxes}

Diel model fits were observed for $\mathrm{N}_{2} \mathrm{O}$ and $\mathrm{CO}_{2}$ fluxes (Fig. 7) with peak fluxes ranging between 14:00 and 17:00, a similar range in time observed for peak air and soil temperature (Fig. 7d). This indicates that $\mathrm{N}_{2} \mathrm{O}$ and $\mathrm{CO}_{2}$ fluxes closely followed diel temperature patterns, a similar finding to Smith et al. (1998) and Alves et al., (2012) in agricultural soils in the UK and Brazil. In both cases, covariation of soil microbial activity with soil temperature is the most parsimonious explanation, although diel patterns of root activity cannot be ruled out for $\mathrm{CO}_{2}$ (Savage et al., 2013).

There was a small diel pattern in $\mathrm{CH}_{4}$ uptake rates (Fig. 7), with an average of $1 \mu \mathrm{g} \mathrm{m}^{-2} \mathrm{~h}^{-1}$ (amplitude) between morning and evening time periods, and the highest rate of $\mathrm{CH}_{4}$ uptake occurring when soils were warmest. The small diel amplitude for $\mathrm{CH}_{4}$ fluxes indicates methanotrophic activity may not be as sensitive to changes in temperature at

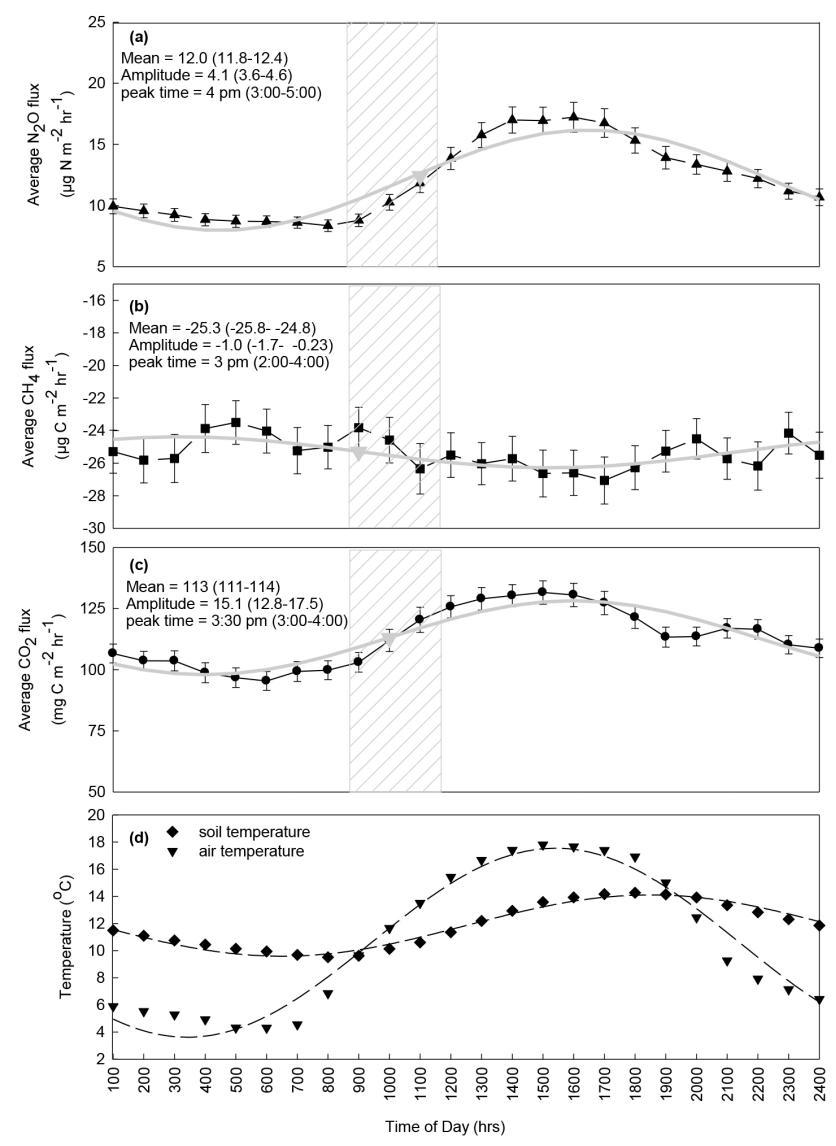

Figure 7. Diel trends from automated measurements of (a) $\mathrm{N}_{2} \mathrm{O}$, (b) $\mathrm{CH}_{4}$, (c) $\mathrm{CO}_{2}$, and (d) soil temperature at $2 \mathrm{~cm}$ and air temperature, for one alfalfa crop cycle. Symbols are the average and standard errors of hourly flux rates per GHG. Grey line is the diel sine wave fit to all data. Grey symbols are the average flux rate for fitted trend, and the grey cross hatch area denotes the time of day manual samples are measured. Diel trends in soil and air temperature are averages per hour.

this timescale as is the microbial activity that produces $\mathrm{N}_{2} \mathrm{O}$ and $\mathrm{CO}_{2}$.

The mean daily GHG flux, calculated from the model fits, occurred between 9:00 and 10:00, which coincides with the time frame (9:00 to noon) in which manual samples are collected in ND. The time period representative of the mean daily flux is an average estimate and may vary slightly on a daily basis. This indicates that the manual sampling technique and sampling time frame utilized in ND are representative of the daily mean flux.

\section{Conclusions}

The new QCLAS system was integrated in line with an existing automated system for measuring soil $\mathrm{CO}_{2}$ flux. The response time and sensitive measurements of $\mathrm{N}_{2} \mathrm{O}$ and $\mathrm{CH}_{4}$ provide confidence in the measurement of small changes in 
chamber headspace concentrations of both gases over a short period of time, thus reducing the time needed per flux measurement, increasing the frequency which sampling can occur, and reducing artifacts or modified soil concentration gradients. In the case of $\mathrm{N}_{2} \mathrm{O}$, the higher sensitivity and improved precision of measurements conferred confidence that the measurement of $\mathrm{N}_{2} \mathrm{O}$ consumption in a forested wetland was significantly different from zero flux. Diel patterns, linked to diel temperature patterns, were demonstrated with the automated system for all GHG fluxes. Manually sampling at a time of day typical of the daily mean flux and at a sampling frequency of three times per week during the growing season captured transient responses of GHGs to precipitation events. However, the influence of hot spots and hot moments, particularly on $\mathrm{N}_{2} \mathrm{O}$ fluxes, has a substantial influence when up-scaling. A combination of high-frequency automated measurements and spatially distributed sampling strategy would need to be employed to capture both hot moments and hot spots respectively. This combination would provide the opportunity to capture and characterize transient responses to rapidly changing environmental conditions and spatial heterogeneity for all three gases, which will be valuable to improve modeling efforts and estimates of annual fluxes of these three important greenhouse gases.

Acknowledgements. The authors are grateful to Mark Zahniser, Dave Nelson and Barry McManus of Aerodyne Research. We would like to thank our colleagues, Holly Hughes, Nicanor Saliendra and Justin Feld.

This work was supported by USDA ARS Integrated Resource Management Project (project 5445-xx10-001-00D) and by NASA (grant no. NNX11AF20G). This study was part of the North American Carbon Program.

Edited by: L. Merbold

\section{References}

Alves, B. J. R., Smith, K. A., Flores, R. A., Cardoso, A. S., Oliveira, W. R. D., Jantalia, C. P., Urquiaga, S., and Boddey, R. M.: Selection of the most suitable sampling time for static chambers for the estimation of daily mean $\mathrm{N}_{2} \mathrm{O}$ flux from soils, Soil Biol. Biochem., 46, 129-135, 2012.

Borken, W., Savage, K., Davidson, E. A., and Trumbore, S. E.: Effects of experimental drought on soil respiration and radiocarbon flux from a temperate forest soil, Glob. Change Biol., 12, 177193, 2006.

Chapuis-Lardy, L., Wrage, N., Metay, A., Chotte, J.-L. and Bernoux, M.: Soils, a sink for $\mathrm{N}_{2} \mathrm{O}$ ?, A review, Glob. Change Biol., 13, 1-17, 2007.

Davidson, E. A.: Pulses of nitric oxide and nitrous oxide flux following wetting of dry soil: an assessment of probable sources and importance relative to annual fluxes, Ecol. Bull., 42, 149155,1992

Davidson, E. A. and Schimel, J. P.: Microbial processes of production and consumption of nitric oxide, nitrous oxide and methane, in: Biogenic Trace Gases: Measuring Emissions from Soil and Water, edited by: Matson, P. A. and Harriss, R. C., Blackwell Science, Oxford, 327-357, 1995.

Davidson, E. A. and Trumbore, S. E.: Gas diffusivity and production of $\mathrm{CO}_{2}$ in deep soils of the eastern Amazon, Tellus B, 47, 550 565,1995 .

Davidson, E. A., Savage, K., Verchot, L. V., and Navarro, R. I.: Minimizing artifacts and biases in chamber-based measurements of soil respiration, Agr. Forest Meteorol., 113, 21-37, 2002.

Davidson, E. A., Richardson, A. D., Savage, K. E., and Hollinger, D. Y.: A distinct seasonal pattern of the ratio of soil respiration to total ecosystem respiration in a spruce-dominated forest, Glob. Change Biol., 12, 230-239, 2006.

Davidson, E. A., Nepstad, D. C., Ishida, F. Y., and Bando, P. M.: Effects of an experimental drought and recovery on soil emissions of carbon dioxide, methane, nitrous oxide, and nitric oxide in a moist tropical forest, Glob. Change Biol., 14, 2582-2590, 2008.

Fernandez, I. J., Rustad, L. E., and Lawrence, G. B.: Estimating total soil mass, nutrient content and trace metals in soils under a low elevation spruce-fir forest, Can. J. Soil Sci., 73, 317-328, 1993.

Firestone, M. K. and Davidson, E. A.: Microbiological basis of NO and $\mathrm{N}_{2} \mathrm{O}$ production and consumption in soil, in: Exchange of trace gases between terrestrial ecosystems and the atmosphere, edited by: Andreae, M. O. and Schimel, D. S., John Wiley \& Sons, New York, 7-21, 1989.

Frasier, R., Ullah, S., and Moore, T. R.: Nitrous oxide consumption potential of well-drained forest soils in southern Quebec, Geomicrobiol. J., 27, 53-60, 2010.

Levine, E. R., Knox, R. G., and Lawrence, W. T.: Relationships between soil properties and vegetation at the Northern Experimental Forest, Howland, Maine, Remote Sens. Environ., 47, 231241, 1994.

Nelson, D. D., McManus, B., Urbanski, S., Herndon, S., and Zahniser, M. S.: High precision measurements of atmospheric nitrous oxide and methane using thermoelectrically cooled midinfrared quantum cascade lasers and detectors, Spectrochim. Acta A, 60, 3325-3335, 2004.

Parkin, T. B.: Effect of sampling frequency on estimates of cumulative nitrous oxide emissions, J. Environ. Qual., 37, 1390-1395, 2008.

Parkin, T. B., Venterea, R. T., and Hargreaves, S. K.: Calculating the detection limits of chamber-based soil greenhouse gas flux measurements, J. Environ. Qual., 41, 705-715, doi:10.2134/jeq2011.0394, 2012.

Phillips, R. L., Tanaka, D., Archer, D., and Hanson, J.: Fertilizer application timing influences greenhouse gas fluxes over a growing season, J. Environ. Qual., 38, 1569-1579, 2009.

Rochette, P. and Eriksen-Hamel, N. S.: Chamber measurements of soil nitrous oxide flux: Are absolute values reliable?, Soil Sci. Soc. Am. J., 72, 331-342, doi:10.2136/sssaj2007.0215, 2008.

Savage, K. E. and Davidson, E. A.: A comparison of manual and automated systems for soil $\mathrm{CO}_{2}$ flux measurements: trade-offs between spatial and temporal resolution, J. Exp. Bot., 54, 891899, 2003.

Savage, K., Davidson, E., and Richardson, A. D.: A conceptual and practical approach to data quality and analysis procedures for high-frequency soil respiration measurements, Funct. Ecol., 22, 1000-1007, 2008 
Savage, K., Davidson, E. A., Richardson, A. D., and Hollinger, D. Y.: Three scales of temporal resolution from automated soil respiration measurements, Ag. For. Met., 149, 2012-2021, 2009.

Savage, K., Davidson, E. A., and Tang, J.: Diel patterns of autotrophic and heterotrophic respiration among phenological stages, Glob. Change Biol., 19, 1151-1159, 2013.

Schlesinger, W.: An estimate of the global sink for nitrous oxide in soils, Glob. Change Biol., 19, 2929-2931, doi:10.1111/gcb.12239, 2013.

Soil Survey Staff: Official soil series description, USDA Washington, DC available at: http://soils.usda.gov/technical/ classification/osd/index.html (last access: 24 April 2009), 2008.

Smith, K. A., Thomson, P. E., Clayton, H., McTaggart, I. P., and Conen, F.: Effects of temperature, water content and nitrogen fertilisation on emissions of nitrous oxide by soils, Atmos. Environ., 19, 3301-3309, 1998.
Smith, K. A. and Dobbie, K. E.: The impact of sampling frequency and sampling times on chamber-based measurements of $\mathrm{N}_{2} \mathrm{O}$ emissions from fertilized soils, Glob. Change Biol., 7, 933-945, 2001.

Ullah, S. and Moore, T. R.: Biogeochemical controls on methane, nitrous oxide, and carbon dioxide fluxes from deciduous forest soils in eastern Canada, J. Geophys. Res., 116, G03010, doi:10.1029/2010JG001525, 2011.

Verchot, L. V., Davidson, E. A., Cattânio, J. H., Ackerman, I. L., Erickson, H. E., and Keller, M.: Land use change and biogeochemical controls of nitrogen oxide emissions from soils in eastern Amazonia, Global Biogeochem. Cy., 13, 31-46, 1999.

Verchot, L. V., Davidson, E. A., Cattânio, J. H., and Ackerman, I. L.: Land-use change and biogeochemical controls of methane fluxes in soils of eastern Amazonia, Ecosystems, 3, 41-56, 2000. 